\title{
Sinergitas dan Kebijakan Pemerintah Terhadap Profesi Dalam Mencegah Kejahatan Pencucian Uang
}

\author{
Fauziah Lubis'1), Fatimah Zahara'2)* \\ 1) Program Studi Hukum Ekonomi Syariah, Fakultas Syari'ah dan Hukum, Universitas \\ Islam Negeri Sumatera, Indonesia \\ 2)Program Studi Hukum Ekonomi Syariah, Fakultas Syari'ah dan Hukum, Universitas Islam \\ Negeri Sumatera, Indonesia, Indonesia
}

\begin{abstract}
Abstrak
Tujuan penelitian ini adalah untuk mendeskripsikan pola integritas dan kebijaan pemerintah dalam mencegah kejahatan pencucian uang. Kejahatan pencucian uang atau kejahatan pencucian uang (TPPU) adalah kejahatan Kerah Putih yang telah menarik perhatian dan keprihatinan luas di antara negara-negara termasuk Indonesia dan memerangi kejahatan pencucian uang. Metode penelitian ini adalah metode penelitian deskriptif kualitatif. Hasil penelitian menunjukkan bahwa bentuk sinergitas pemerintah dalam mencegah kejahatan pencucian uang yaitu dengan bekerjasama dengan aparat penegak hukum, akademisi, masyarakat, tokoh-tokoh agama, professional dan PPATK, kemudian juga terdapat suatu kebijakan yang dilakukan pemerintah tertuang dalam Peraturan Pemerintah No. 43 tahun 2015 bahwa profesi diwajibkan untuk melaporkan kegiatan transaksi yang mencurigakan. Regulasi tersebut belum berlaku jika profesi mendapati adanya transaks seperti pembelian dan penjualan properti, pengelolaan uang, sekuritas, dan/atau produk layanan keuangan lainnya, manajemen rekening giro, rekening tabungan, dan akun sekuritas, operasi dan manajemen perusahaan; dan/atau pendirian, pembelian. Namun, demikian dengan adanya kekuatan kebijakan dan regulasi tersebut belum mampu untuk membendung eskalasi praktik pencucian uang, sehingga dibutuhkan integritas yang tinggi dalam menyelesaikan kejahatan tersebut baik oleh pemerintah, masyarakat, penegak hukum, tokoh-tokoh dan lainnya.
\end{abstract}

Kata Kunci: Kebijakan, Kejahatan, Pencucian Uang, Peraturan, Pemerintah

\begin{abstract}
The purpose of this study is to describe the pattern of government integrity and policies in preventing money laundering crimes. Money laundering or money laundering (TPPU) crimes are White Collar crimes that have attracted widespread attention and concern among countries including Indonesia and combating money laundering crimes. This research method is a descriptive qualitative research method. The results showed that the form of government in preventing money laundering crimes is by collaborating with law enforcement officials, academics, the community, religious leaders, professionals and PPATK, then there is also a policy made by the government contained in Government Regulation No. 43 of 2015 that the profession is required to report suspicious transaction activities. The regulation does not apply if the profession finds transactions such as buying and selling property, money management, securities, and / or other financial service products, current account management, savings accounts, and securities accounts, company operations and management; and / or establishment, purchase. However, the strength of the policies and regulations has not been able to stem the escalation of money laundering practices, so that high integrity is needed in resolving these crimes both by the government, the community, law enforcement, figures and others.
\end{abstract}

Keywords: Policy, Crime, Money Laundering, Regulations, Government

How to Cite: Lubis, F. \& Zahra, F. (2020). Sinergitas dan Kebijakan Pemerintah Dalam Mencegah dan Memberantas Kejahatan Pencucian Uang. PUBLIKAUMA: Jurnal Administrasi Publik, UMA, Vol 8 (1): $57-$ 62

${ }^{*}$ Corresponding author:
E-mail: fauziahlubis2018@gmail.com ISSN 2549-166o (Print) ISSN 2550-1305 (Online) 


\section{PENDAHULUAN}

Tindakan pencucian uang adalah cara penjahat untuk melakukan kejahatan dengan cara menyamarkan hasil-hasil keuntungan yang didapatkannya dari kegiatan atau usaha illegal. Kejahatan tersebut terkategori seperti para penjahat baik itu penyelundup narkoba, penjahat terorganisir, teroris, penyelundup senjata, pemeras, atau penipu kartu kredit menyamarkan asal-usul uang kriminal mereka sehingga mereka dapat menghindari deteksi dan risiko penuntutan saat mereka menggunakannya.

Pencucian uang sangat penting dan efektif untuk diselidiki karena merupakan bentuk kejahatan transnasional dan terorganisir. Upaya anti-pencucian uang, yang dirancang untuk mencegah atau membatasi kemampuan para penjahat untuk menggunakan keuntungan mereka, merupakan komponen penting dan efektif dari program anti-kejahatan (Jhon, 2001).

Pencucian uang umumnya melibatkan serangkaian transaksi ganda yang digunakan untuk menyamarkan sumber aset keuangan sehingga aset tersebut dapat digunakan tanpa membahayakan para penjahat yang ingin menggunakannya. Transaksi ini biasanya terbagi dalam tiga tahap: (1) penempatan proses menempatkan hasil yang melanggar hukum ke lembaga keuangan melalui deposito, transfer kawat, atau cara lain; (2) layering proses pemisahan. Hasil kegiatan kriminal dari asalnya melalui penggunaan lapisan transaksi keuangan yang rumit; dan (3) integrasi proses menggunakan transaksi yang tampaknya sah untuk menyamarkan hasil terlarang. Melalui proses-proses ini, seorang penjahat mencoba mengubah hasil moneter yang diperoleh dari kegiatan terlarang menjadi dana dengan sumber yang tampaknya sah.

Tindak Pidana Pencucian Uang (TPPU) atau yang sering dikenal dengan istilah money laundering ini merupakan salah satu kejahatan White Collar Crime yang banyak menarik perhatian dan keprihatinan dunia Internasional termasuk Indonesia. Hal tersebut lazim adanya mengingat dampak yang diakibatkan oleh aksi TPPU sangatlah luar biasa, yakni selain mengancam stabilitas perekonomian dan integritas sistem keuangan, tetapi juga dapat membahayakan sendi-sendi kehidupan bermasyarakat, berbangsa, dan bernegara berdasarkan Pancasila dan UndangUndang Dasar Negara Republik Indonesia Tahun 1945.

Problematika pencucian uang yang dikenal dengan nama "money laundry" banyak menyita perhatian dunia international disebabkan dimensi dan implikasinya yang melanggar batas-batas negara. Sebagai suatu fenomena kejahatan yang menyangkut terutama dunia kejahatan yang dinamakan "organized crime", ternyata ada pihak pihak tertentu yang ikut menikmati keuntungan dari lalu lintas pencucian uang tanpa menyadari akan dampak kerugian yang ditimbulkan. Ada berbagai rumusan bertalian dengan makna pencucian uang atau "money laundry" pada dasarnya perumusan itu menyangkut suatu proses pencucian uang yang diperoleh dari kejahatan dan dicuci melalui suatu lembaga keuangan (bank) atau penyedia jasa keuangan, sehingga pada akhirnya uang yang haram itu mendapatkan suatu penampilan sebagai uang yang sah atau halal (Fransiska, 2011).

Masalah pencucian uang telah menarik perhatian nasional karena dimensi dan implikasinya yang melanggar batas negara. Operasi TPPU di Indonesia telah beroperasi sejak diberlakukannya Undang-Undang Nomor 15 Tahun 2002 tentang Pencucian Uang sebagaimana telah diubah dengan UU No. 25 Tahun 2003 tentang Perubahan dalam Undang-Undang Nomor 15 Tahun 2002 tentang Pencucian Uang. Hukum telah menunjukkan arah positif. Selain itu, keberadaan tindak pidana yang disebutkan dalam Pasal 2 UU No. 8 tahun 2010 tentang dugaan pencucian uang tidak perlu dikuatkan terlebih dahulu, jika ada dakwaan bahwa uang tersebut berasal dari korupsi, yang menyatakan bahwa ada dua fakta sebagai bukti asal. Kriminalisasi pencucian uang ilegal telah memenuhi syarat sebagai kejahatan kerah putih (Yani, 2013).

Sejak diperkenalkannya Peraturan Pemerintah No. 43 tahun 2015 tentang Pengaduan dan Pihak Pengaduan Anti Pencucian Uang pada Juni 2015, Pusat Analisis Transaksi Keuangan (PPATK) telah mengoptimalkan keberhasilan dalam mengimplementasikan keputusan tersebut. Bisnis yang dilakukan oleh PPATK meliputi 
koordinasi dan komunikasi terkait dengan mempercepat persiapan persyaratan peraturan tentang prinsip-prinsip mengakui pengguna jasa untuk profesi, serta sosialisasi dan pelatihan untuk profesi kerja. Para profesional ketenagakerjaan yang berkomitmen untuk menjadi pengadu adalah advokat, notaris, tuan tanah, akuntan, akuntan publik, dan perencana keuangan. Profesi kerja diminta untuk berpartisipasi dalam mencegah dan menghilangkan pencucian uang. Berdasarkan temuan investigasi PPATK, sangat rentan untuk digunakan oleh penjahat investasi ilegal untuk menyembunyikan atau mengaburkan asal-usul properti yang merupakan hasil dari tindak pidana dengan bersembunyi di balik Ketentuan mengenai Kerahasiaan Pekerjaan, Hubungan Profesional dengan Pengguna Layanan sebagaimana diatur dalam undang-undang (Laporan Buletin), 2017). Dalam hal ini profesi-profesi tersebut digunakan sebagai penjaga gerbang oleh penjahat pencucian uang (Utama, 2013).

Profesi sebagaimana diatur dalam Peraturan Pemerintah (PP No. 43 Tahun 2015) wajib melaporkan transaksi mencurigakan ke PPATK. Tugas pengaduan tidak berjalan mulus. Misalnya, menolak ketentuan pengaduan ke PPATK. Profesi dapat mendeteksi transaksi, proses dan metode dalam proses perubahan yang tidak dapat dipisahkan. Jika transaksi keuangan antara pembukuan dan perdagangan seimbang, maka transaksi itu kemungkinan benar.

Padahal, dalam transaksi sudah masuk uang hasil (hasil tindak pidana). Sistem transaksi bisnis adalah cara yang sah untuk memasukkan uang yang dihasilkan dari tindak pidana ke dalam transaksi keuangan. Setelah masuk ke dalam sistem transaksi bisnis yang sah, itu dicampur dengan uang lainnya. Masuknya uang kriminal ke dalam sistem transaksi bisnis yang sah adalah proses menempatkan uang ke dalam bisnis. Kedua, profesi dapat menemukan uang bercampur dengan uang lain dalam bisnis dan menjadikannya legal, dilapisi, ditutupi, dikelilingi, dan bercampur dengan hasil bisnis yang sah. Jika uang itu dihabiskan atau digunakan, maka itu akan menjadi bagian dari pendapatan bisnis yang sah karena asalnya tidak lagi terlihat. Bahkan, pemain pencucian uang (TPPU) dapat menggunakan layanan profesional mereka sebagai penjaga gerbang dalam pencucian uang. Terdakwa, Notaris, PPAT diperlukan sebagai pelapor atas Transaksi Keuangan Mencurigakan (TKM) di TPPU untuk setidaknya dua alasan.

Salah satu contoh investasi uang ilegal adalah oleh Alphonse Capone. Pengungkapan kejahatan Alphonse Capone adalah pengingat penting kejahatan terorganisir. Pengungkapan kasus Alphonse Capone adalah tonggak penting dalam sejarah penegakan hukum. Untuk pertama kalinya, penjahat dapat dihukum penjara tidak hanya karena mereka berpartisipasi atau berpartisipasi dalam pembunuhan, pemerasan atau penjualan obatobatan terlarang, tetapi hanya karena mereka mendapatkan uang tetapi tidak melaporkannya ke pihak berwenang (Yusuf, 2014).

Selain itu, peran profesi dalam mencegah dan memberantas pencucian uang berdampak buruk bagi banyak orang. Berdasarkan data terakhir, ada 168 kasus pencucian uang TPPU yang diputuskan oleh Pengadilan dari Januari 2005 hingga Desember 2017. Selama periode ini, sebagian besar keputusan Pengadilan terkait dengan TPPU diputuskan oleh Pengadilan (termasuk Pengadilan Negeri/ Pengadilan Tinggi, Pengadilan Tinggi dan Pengadilan Tinggi). atau Mahkamah Agung) dari Wilayah DKI Jakarta, yang merupakan 70 keputusan atau 41,7 persen. Salah satunya adalah tindak pidana pencucian uang oleh sebuah perusahaan yang diduga terlibat korupsi dalam pembangunan Bendungan Teluk Radang, Karimun, yang mengakibatkan kerugian sebesar Rp 3,2 miliar (Laporan Buletin PPATK, 2018).

Masalah ini tidak dapat dipisahkan dari sistem kebijakan dan hukum yang lemah. Sistem hukum secara keseluruhan adalah kesatuan tubuh termasuk substansi (substansi), struktur (struktur) dan budaya hukum (budaya hukum). Dalam kesimpulan lain, Lawrence Meir Friedman, mendefinisikan hukum sebagai sistem tiga (tiga) komponen, yaitu: struktur hukum, legalitas, dan budaya hukum (Friedman, 2001). Berdasarkan uraian di atas, dipahami bahwa uji tuntas diperlukan untuk menganalisis peran hukum profesi sebagai pelapor dalam mencegah dan mencegah pencucian uang. 


\section{METODE PENELITIAN}

Jenis metode penelitian yang digunakan dalam penelitian ini adalah metode penelitian deskriptif kualitatif menggunakan bahan data primer, bahan sekunder dan bahan hukum tersier. Spesifikasi penelitian ini khusus untuk menganalisis integritas dan kebijakan pemerintah serta bagaimana peraturan tersebut bekerja di masyarakat. Teknik pengumpulan data menggunakan wawancara difokuskan pada data sekunder. Penelitian ini juga melakukan analisis terhadap Peraturan Pemerintah Nomor 43 Tahun 2015 terkait pencucian uang. Peneliti melakukan wawancara dengan informan, khususnya pada Departemen Hubungan Masyarakat Analisis dan Analisis Transaksi Keuangan (PPATK) dan profesi. Untuk mendapatkan informasi sebagai pelengkap untuk melengkapi data sekunder.

Alat pengumpulan data dalam penelitian pedoman wawancara dan peraturan pemerintah berasal dari data sekunder dengan tujuan memperoleh konsep, teori dan informasi serta pemikiran konseptual dari peneliti sebelumnya dalam bentuk, makalah ilmiah, jurnal dan banyak lagi. Analisis data dimulai dengan memeriksa data yang dikumpulkan dan kemudian melakukan wawancara langsung dan langsung. Selain itu, analisis data kualitatif dilakukan sehingga dapat dikaitkan dengan kerangka kerja teoritis untuk mendapatkan jawaban atas pertanyaan masalah yang diteliti.

\section{HASIL DAN PEMBAHASAN}

Undang-undang, yang mulai berlaku melalui Peraturan Kekuatan Tinggi No. 43 tahun 2015, menangani kasus-kasus pencucian uang yang belum efektif. Hal ini disebabkan oleh lemahnya sistem kerjasama antara kelalaian yang terlibat antara PPATK (Pusat Pelaporan Keuangan dan Analisis Transaksi), polisi, pihak berwenang yang bertanggung jawab untuk menangani TTPU di Indonesia atau pencucian uang. Semua agensi yang terlibat tertarik pada diri sendiri dan tidak bekerja sama dengan baik. Menurut (Friedman, 2001) untuk menghasilkan aturan yang perlu ditegakkan dalam sistem kebijakan, itu adalah tatanan persatuan yang jelas yang mencakup cara hukum disusun yang mencakup keadilan hukum dan budaya. Peran seorang profesi yang berspesialisasi dalam menegakkan persyaratan hukum dan peraturan dari kasus pencucian uang, masingmasing pihak dengan keahlian tersebut harus bertanggung jawab untuk melaporkan semua informasi.

Lebih jauh, profesi juga membutuhkan keterampilan yang tidak terduga dengan beban tanggung jawab yang besar dan upaya untuk menegakkan hukum. Di antara perangkat lunak hukum adalah aturan otoritas tertinggi dan mengharuskan profesional yang terampil untuk melaporkan dalam mencegah dan menekan tindakan pelanggar atau penjahat dalam transaksi ilegal yang budaya hukumnya sejalan dengan aturan yang diberlakukan oleh pihak berwenang yang membentuk sikap, dan tindakan masyarakat yang menentukan nilai-nilai kegiatan seharihari masyarakat, baik atau buruk. Kekuatan sosial masyarakat mempengaruhi cara masyarakat berpikir dan menentukan bagaimana suatu hukum dibuat dan diimplementasikan. Studi ini juga memiliki pola pemersatu dari agen-agen yang terlibat yang dapat melakukan pekerjaan dengan lingkup pekerjaan yang lebih jelas. Seperti yang ditunjukkan pada diagram berikut:

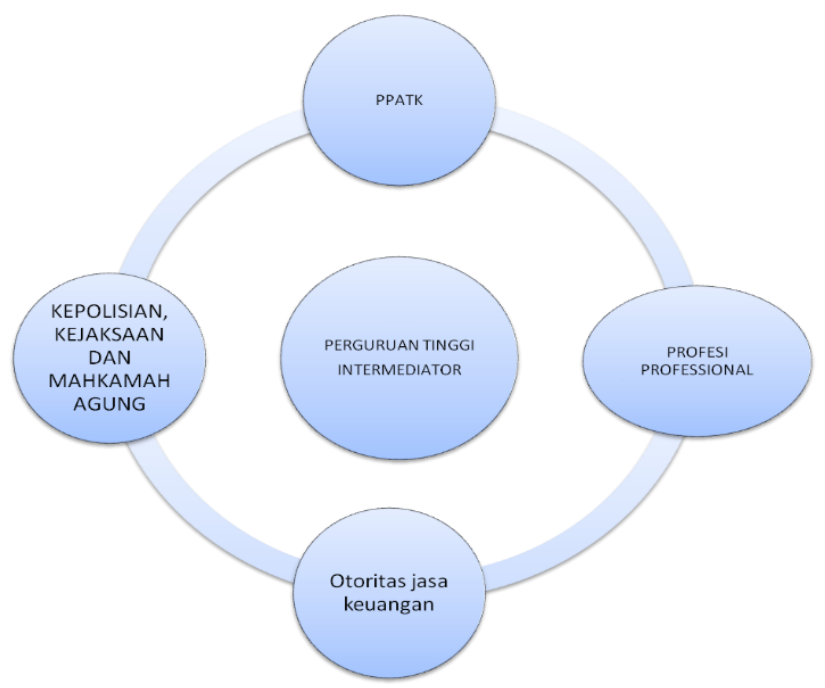

Gambar 1. Model Reciprocal Cyclus Penguatan Sistem Hukum Dalam Mencegah dan Memberantas TPPU (Sumber: Ediwarman, 2014

Gambar diatas merupakan bentuk sinagitas berbagai elememen dalam mencegah kejahatan pencucian uang. Seperti sinergitas antara aparat penegak hukum, akademisi, 
masyarakat, Dewan Perwakilan Rakyat, Profesi PPATK dan tokoh-tokoh. Ini membuktikan bahwa sinergitas merupakan hal mutlak sebagai wujud keseriusan pemerintah dalam mencegah kjahatan pencucian uang.

Lebih lanjut, kerugian dari penerapan pencegahan gagal menafsirkan kode teknis para ahli, sebagaimana dinyatakan oleh PP. Nomor 43 tahun 2015 tentang spesialis atau otoritas yang terlibat dalam pencegahan dan penghapusan adalah pengacara, PPAT, akuntan, akuntan umum, dan regulator keuangan. Masing-masing spesialisasi ini memiliki caranya sendiri dalam berurusan dengan kliennya. Dalam Undang-Undang No. 43 Tahun 2015 masing-masing pihak harus melaporkan transaksi keuangan yang mencurigakan seperti pembelian dan penjualan real estat, penggunaan pencucian uang, dan jenis layanan tertentu yang ditawarkan. Seperti koperasi, perusahaan, perbankan dan transaksi pencucian uang. Namun, atasan juga mengelola penerbitan kewajiban untuk melaporkan keahlian apa pun yang bertindak untuk kepentingan atau atas nama kliennya. Dapat dikatakan bahwa dalam menyusun kenijakan dan peraturan perlu untuk memastikan posisi profesional para ahli di bidang-bidang tertentu.

Hal yang sedang dieksplorasi adalah bagaimana menemukan "kode" rahasia yang dapat melawan pencucian uang yang memberikan kesadaran kepada para ahli yang terlibat. Hal ini dapat dibuktikan dengan (purnomo 2016) bahwa peran profesi adalah sebagai pelapor tanpa perencanaan apa pun. Hal ini dinyatakan dalam PPATK atau UndangUndang Nomor 8 Tahun 2010.

Agar kebijakan dapat ditegakkan diperlukan alat negara yang diserahi tugas dan tanggung jawab untuk menegakkan hukum, dengan kewenangan tertentu, memaksakan agar ketentuan hukum ditaati. Hal ini menurut Mochtar Kusuma Atmaja dikatakan bahwa : " Hukum tanpa kekuasaan adalah angan-angan, sedangkan kekuasaan tanpa hukum adalah kelaliman". Sehingga untuk tegaknya hukum perlu kekuasaan yang mendukungnya, juga sebaliknya kekuasaan harus dibatasi kewenangannya oleh aturanaturan hukum. Berbicara mengenai penegakan hukum, maka tentu ada yang menegakkan hukum, yaitu penegak hukum. Secara sosiologis setiap penegak hukum mempunyai kedudukan dan peranan. Hal ini akan di uraikan kemudian pada saat menguraikan faktor-faktor yang mempengaruhi penegakan hukum. Masalah pokok dari penegakan hukum tindak pidana pencucian uang sebenarnya terletak pada faktor- faktor yang mungkin mempengaruhinya yaitu :

1. Faktor hukumnya sendiri, yang dalam hal ini hanya terbatas pada undang- undang.

2. Faktor hukumnya sendiri yang harus menjadi persyaratan utama adalah mempunyai cukup kejelasan makna dan arti ketentuan, tidak adanya kekosongan karena belum ada peraturan pelaksanaanya, peraturan tersebut sinkron secara vertikal dan horizontal sehingga mengurangi luasnya interprestasi petugas hukum.

3. Faktor penegak hukum. Secara sosiologis, antara hukum dan pelaksana hukum merupakan dua hal yang berbeda hukum termasuk perundang-undangan dan berbagai azas hukum yang mendasarinya merupakan suatu yang abstrak, sebaliknya peningkatan hukum termasuk bekerjanya Pengadilan merupakan suatu yang konkret. Penghubung antara yang abstrak dan konkrek itu dalam penegakan hukum adalah penegak hukum, utamanya para hakim di Pengadilan.

Secara sosiologis setiap penegak hukum mempunyai kedudukan dan peranan. Kedudukan merupakan posisi tertentu dalam struktur kemasyarakatan yang mungkin tinggi, sedang atau rendah. Kedudukan tersebut merupakan suatu wadah yang isinya adalah hak-hak dan kewajiban-kewajiban tertentu. Hak-hak dan kewajiban-kewajiban tadi merupakan peranan. Oleh karena itu maka seseorang mempunyai kedudukan tertentu lazimnya dinamakan pemegang peranan. Suatu hak sebenarnya merupakan wewenang untuk berbuat atau tidak berbuat sedangkan kewajiban adalah beban atau tugas. Suatu peranan berfungsi apabila sesorang berhubungan dengan pihak lain atau dengan beberapa pihak. Peranan tersebut dapat berupa peranan yang ideal, peranan yang seharusnya dan peranan yang aktual. Peranan yang seharusnya dari penegak hukum tertentu, telah dirumuskan dalam undangundang. Disamping itu didalam undang- 
undang tersebut juga dirumuskan perihal peran ideal.

\section{SIMPULAN}

Bentuk sinergitas pemerintah dalam mencegah kejahatan pencucian uang yaitu dengan bekerjasama dengan aparat penegak hukum, akademisi, masyarakat, tokoh-tokoh agama, professional dan PPATK, kemudian juga terdapat suatu kebijakan yang dilakukan pemerintah tertuang dalam Peraturan Pemerintah No. 43 tahun 2015 bahwa profesi diwajibkan untuk melaporkan kegiatan transaksi yang mencurigakan. Regulasi tersebut belum berlaku jika profesi mendapati adanya transaks seperti pembelian dan penjualan properti, pengelolaan uang, sekuritas, dan/atau produk layanan keuangan lainnya, manajemen rekening giro, rekening tabungan, dan akun sekuritas, operasi dan manajemen perusahaan; dan/atau pendirian, pembelian. Namun, demikian dengan adanya kekuatan kebijakan dan regulasi tersebut belum mampu untuk membendung eskalasi praktik pencucian uang, sehingga dibutuhkan integritas yang tinggi dalam menyelesaikan kejahatan tersebut baik oleh pemerintah, masyarakat, penegak hukum, tokoh-tokoh dan lainnya. Kekuasaan harus dibatasi kewenangannya oleh kbeijakan dan aturanaturan hukum karena secara sosiologis setiap penegak hukum mempunyai kedudukan dan peranan.

\section{DAFTAR PUSTAKA}

PPATK, (2017). Buletin Laporan Pusat Pelaporan Analisis Tranksaksi Keuangan. Jakarta: PPATK

PPATK, (2018). Buletin Laporan Pusat Pelaporan Analisis Tranksaksi Keuangan. Jakarta: PPATK

Ediwarman, (2014). Penegakan Hukum Pidana Dalam Perspektif Kriminologi. Jogjakarta: Genta Publishing

Fransiska, N.E. (2011). "Tindak Pidana Pencucian Uang" , Jurnal Hukum Vol XXVI, No. 2, Agustus hal.640-641

Friedman, M, Lawrence. (2001). Hukum Amerika Sebuah Pengantar, Jakarta: Tatanusa

Transaksi Keuangan

John McDowell. 2001. Senior Policy Adviser, and Gary Novis, Program Analyst, Bureau of International Narcotics and Law Enforcement Affairs, U.S. Department of State. Artikel The
Consequences Of Money Laundering And Financial Crime Economic Perspectives, An Electronic Journal of the U.S. Department of State, Vol. 6, No. 2

Peraturan Pemerintah Nomor 43 Tahun 2015 tentang Pihak Pelapor dalam Pencegahan dan Pemberantasan Tindak Pidana Pencucian Uang

Purnomo, R, dkk. (2016). Pengaturan Wajib Lapor Advokat Dalam Pencegahan dan Pemberantasan Tindak Pidana Pencucian Uang Berdasarkan Peraturan Pemerintah Nomor 43 Tahun 2015 Tentang Pihak Pelapor Dalam Pencegahan dan Pemberantasan Tindak Pidana Pencucian Uang. Jurnal Diponegoro Law Review. Volume 5 Nomor 2, hal 1-2

Utama, P. (2013). Memahami Asset Recovery dan Gatekeeper, Jakarta: Indonesian Legal Roundtable

Yani, A, M. (2013). Kejahatan Pencucian Uang (Money Laundering) (Tinjauan UndangUndang Nomor 8 Tahun 2010 Tentang Pencegahan Dan Pemberantasan Tindak Pidana Pencucian Uang. E-Journal WIDYA Yustisia. Volume 1 Nomor 1, hal 1-2

Yusuf, M, (2014). Mengenal, Mencegah, Memberantas Tindak Pidana Pencucian Uang, Jakarta: Pusat Pelaporan dan Analisis 